\title{
SEDIMENTARY STEROLS AS INDICATORS OF ENVIRONMENTAL CONDITIONS IN SOUTHEASTERN GUANABARA BAY, BRAZIL
}

\author{
Elisamara Sabadini Santos ${ }^{1}$, Renato da Silva Carreira ${ }^{2, *}$ and Bastiaan Adrian Knoppers ${ }^{I}$ \\ ${ }^{1}$ Universidade Federal Fluminense - Programa de Pós-Graduação em Geoquímica \\ (Outeiro São João Batista, s/n, Centro 24020-007, Niterói, RJ, Brasil) \\ ${ }^{2}$ Universidade do Estado do Rio de Janeiro - Faculdade de Oceanografia/LaGOM \\ (Rua São Francisco Xavier, 524, Maracanã 20550-013, Rio de Janeiro, RJ, Brasil) \\ *corresponding author: carreira@uerj.br
}

\begin{abstract}
A B S T R A C T
The interconnected Icaraí and Jurujuba embayments, set within the lower south-eastern portion of Guanabara Bay, SE-Brazil, have been subject to the direct input of domestic effluents and other associated contaminants from human activities in their watersheds. This study addresses the composition of carbon, nitrogen and molecular steroid markers of surface sediments $(n=24)$ and a short core $(\mathrm{L}=47 \mathrm{~cm})$, in order to evaluate the impact by sewage, the contribution between allochthonous and autochthonous derived organic matter and eutrophication of the embayments. Coprostanol concentrations revealed, when compared to other regions in Guanabara Bay, high contamination by sewage close to the point of sewage discharge in Icaraí embayment. In contrast, the more enclosed and eutrophic Jurujuba embayment exhibited a larger contribution of autochthonous organic matter, as shown by the combination of cholesterol, dinosterol and, partially, also brassicasterol. The presence of stigmasterol and $\beta$-sitosterol also indicated a minor contribution of organic matter from terrestrial plants, as revealed by principal component analysis. The sedimentary record of the Jurujuba embayment exhibited highest concentrations of all sterol markers in the top layer, corroborating the recent increase in the accumulation of sewage, plankton derived organic carbon and also eutrophication. Trend in degradation of organic matter was evidenced by sterol/stanol ratios and the behavior of dinosterol indicated that the embayment has been dominated by the accumulation of phytoplankton derived organic matter since earlier times.
\end{abstract}

\section{ReSUMO}

As enseadas de Icaraí e Jurujuba, localizadas na porção sudoeste da Baía de Guanabara, são sujeitas a impactos ambientais decorrentes da ocupação humana nas suas bacias de drenagem. No presente trabalho foi determinada a composição elementar $(\mathrm{C}$ e N) e molecular (esteróides) da matéria orgânica em amostras de sedimentos superficiais $(n=24)$ e de um testemunho curto $(\mathrm{c}=47 \mathrm{~cm})$ nas enseadas. As concentrações de coprostanol, em comparação com outras áreas da Baía de Guanabara, indicaram elevado nível de contaminação por esgotos nas estações mais próximas ao ponto de lançamento de efluentes, na Enseada de Icaraí. A Enseada de Jurujuba, mais enclausurada e eutrófica, apresentou uma maior contribuição de matéria orgânica autóctone, conforme evidenciado pelos marcadores colesterol, dinosterol, e parcialmente, também, brassicasterol. A presença de estigmasterol e $\beta$-sitosterol indicaram leve contribuição de matéria orgânica oriunda de vegetação terrestre, conforme revelou a análise por componentes principais. No registro sedimentar, foram observados maiores teores de matéria orgânica e esteróis na camada superior, corroborando a acumulação recente de esgotos e de matéria orgânica fitoplanctônica, como conseqüência do processo de eutrofização do sistema. A presença de processos de degradação da matéria orgânica foi evidenciada pelas razões entre esteróis/estanóis, e o perfil do dinosterol indicou que na Enseada predomina o acúmulo de material fitoplanctônico anteriormente ao processo de eutrofização.

Descriptors: Organic matter, Sterols, Sediments, Sewage, Eutrophication, Tropical estuary, Guanabara Bay, Brazil.

Descritores: Matéria orgânica, Esteróis, Sedimentos, Esgoto, Eutrofização, Estuário tropical, Baía de Guanabara, Brasil. 


\section{INTRODUCTION}

Estuaries function as mixing bowls for a complex array of allochthonous and autochthonous labile and refractory organic compounds. These are either transformed by physical-chemical and biological particle-water reactions during estuarine mixing, retained within the estuary by accumulation in the sediments or bypassed to the sea without reactions (CANUEL, 2001; GOÑI et al., 2003; HOBBIE, 2000; JAFFÉ et al., 2001; TURNER; MILLWARD, 2002). In addition, most estuaries are nowadays subject to the input of anthropogenic compounds, inducing shifts in the natural balance between allochthonous and autochthonous organic matter and system metabolism as a whole (HEDGES, 1992; MACKENZIE et al., 1993; VER et al., 1999). To elucidate the origin, cycling and fate of the organic compounds in estuarine systems, multi-parameter approaches describing their bulk, isotopic and molecular composition have been adopted (CARREIRA et al., 2002; COUNTWAY et al., 2007; MARTINS et al., 2007; PENG et al., 2005; SALIOT et al., 2002; ZIMMERMAN; CANUEL, 2002).

Lipids, including steroidal alcohols and ketones, belong to one of the categories of molecular markers currently in use to elucidate the presence of natural and anthropogenic organic matter in water and sediments, as they are source specific, relatively resistant to microbial degradation and may be quantified at low levels (CANUEL, 2001; SALIOT et al., 1991). Coprostanol, produced in the gut of higher animals and the human intestine by the bacterial reduction of cholesterol (McCALLEY et al., 1981), has been extensively used on a mass basis or relative to other compounds (i.e. ratios) to indicate fecal contamination (CARREIRA et al., 2004; CHALAUX et al., 1995; EGANHOUSE; SHERBLOM, 2001; FERNANDES et al., 1999; JAFFÉ et al., 2003; JENG et al., 1996; LEEMING et al., 1996; MUDGE; LINTERN, 1999; READMAN et al., 2005). In addition, as coprostanol is relatively stable under anoxic sedimentary conditions (BARTLETT, 1987; NISHIMURA, 1982), it renders a suitable indicator to reconstruct the history of sewage impact over decadal time-scales (CARREIRA et al., 2004; JENG ; HAN, 1996; PENG et al., 2002).

Other sterols, as dinosterol and brassicasterol or fucosterol are specific for dinoflagellates and diatoms, respectively, giving support to short term studies on phytoplankton successional patterns in the water and longer term reconstruction of system population changes in sediment cores. In addition, sterols as $\beta$-sitosterol, stigmasterol and campesterol help to assess the contribution by vascular plants to the organic pool (VOLKMAN, 1986; VOLKMAN et al., 1998).

The present study describes the distribution of coprostanol and other steroidal compounds in sediments of a partially enclosed embayment (Jurujuba and Icaraí Sounds) in the southeastern portion of Guanabara Bay, Rio de Janeiro, Brazil (Fig. 1). The sampling strategy covered a station grid of surface sediments set between the sewage point sources and the marine end-member of the embayment, as well as a sediment core taken in the center of the embayment to reconstruct the historical record of environmental changes related to human activities in its watershed. As this study was performed shortly prior to the completion of a marine outfall in the area, the results should serve as a baseline for future monitoring of the outfalls mitigation of sewage induced eutrophication in the embayment.

\section{Material and Methods}

\section{Study Area}

The Icaraí-Jurujuba embayment is located in the lower southeastern portion of Guanabara Bay, SEBrazil (Lat. $22^{\circ} 55^{\prime} \mathrm{S}$ and Long. $43^{\circ} 07^{\prime} \mathrm{W}$, Fig. 1). It has a water surface area of $9 \mathrm{~km}^{2}$, a mean-depth of 3.3 $\mathrm{m}$ and a water volume of $30 \times 10^{6} \mathrm{~m}^{3}$. The embayment is divided into four distinct sedimentological realms (BAPTISTA-NETO et al., 1999; BAPTISTA-NETO et al., 2000). The western entrance, reflecting the marine influence from the lower portion of Guanabara Bay, contains a mixture of silty-clay sediments and the eastern more enclosed portion of Jurujuba is governed by organic rich clay sediments (organic carbon $=3$ to $5 \%$ ). Some coarser mixed sediments edge the embayments as a narrow film, attributed to the input from eroded slopes after deforestation (BAPTISTANETO et al., 1999).

Over the last five decades, the region has been affected by increasing loads of untreated sewage produced from a large fraction of the inhabitants of the city of Niterói. Sewage is nowadays being discharged after primary treatment beyond the embayment into the adjacent lower central channel of Guanabara Bay by a submarine outfall completed in 2000, as part of the ongoing Guanabara Bay Pollution Mitigation Program (http://www.cibg.rj.gov.br). Before the outfall, the artificial Ary Parreira Channel of the Icarai River introduced sewage with a mean flow of 0.63 $\mathrm{m}^{3} \mathrm{~s}^{-1}$, accounting for $52 \%$ of the total sewage net collection of the Niterói municipality. The outfalls mean discharge is now $0.85 \mathrm{~m}^{3} \mathrm{~s}^{-1}$. Other minor diffuse sources do exist in the region, especially in the Jurujuba embayment, although there is no information about their magnitude. 


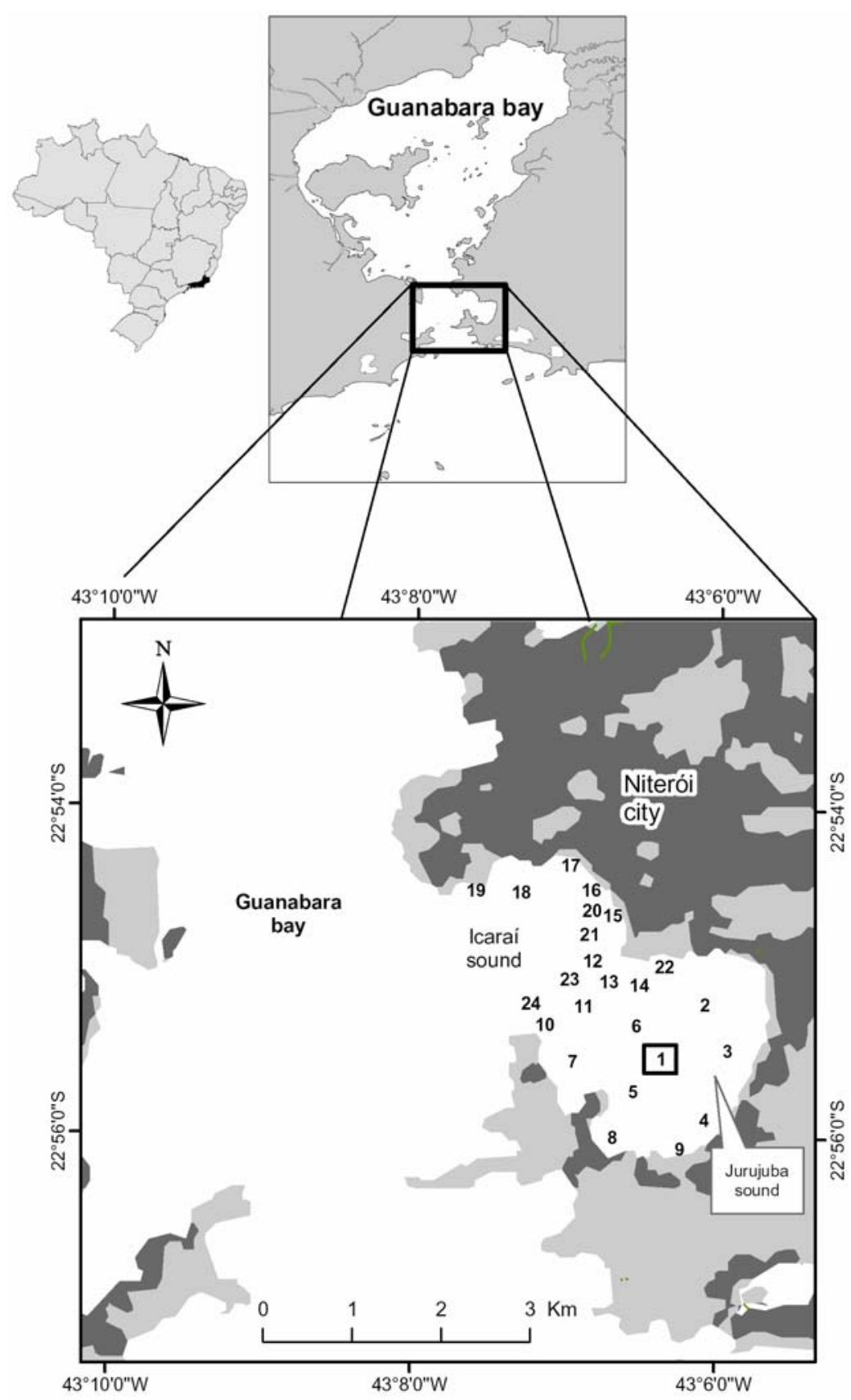

Fig.1. Sampling stations for superficial sediments in southeastern Guanabara Bay. A sediment core was collected at station 1 (open square). Urbanized areas in the continent are indicated by dark grey.

\section{Sampling Procedure}

Sampling of surface sediments was performed on August 15, 2000, covering a grid of 24 stations set between the inward and outward boundaries of the embayment (Fig. 1). Sampling stations for surface sediments were defined giving 
priority to locations dominated by silty-clay sediments as described by Baptista-Neto et al. (1999)., and in the proximity of the main effluent source, the Ary Parreira Channel (stations 15, 16, 20 and 21; Fig. 1). The sediment was collected with a Van Veen grab (Hydrobios, Kiel) and the surface layer $(0-3 \mathrm{~cm})$ was carefully sub-sampled with a metallic spatula directly to aluminum containers, pre-cleaned with $0.1 \mathrm{~mol}^{-\mathrm{L}^{-1}}$ $\mathrm{HCL}$ and heating at $450^{\circ} \mathrm{C}$ overnight. All samples were kept under ice and in the dark on board the sampling boat and stored at $-18^{\circ} \mathrm{C}$ in the laboratory until analysis.

A $50 \mathrm{~cm}$ long sediment core was also collected at station 1 in the Jurujuba embayment (Fig. 1 ), in order to reconstruct the recent depositional patterns of organic matter and associated sterols. The core was sliced at $2 \mathrm{~cm}$ intervals and the samples treated and stored as described for the superficial samples.

\section{Methods and Instrumentation}

Total organic carbon (TOC) and nitrogen (TN) were determined, in all the 24 collected samples, on the sediment fraction $<63 \mu \mathrm{m}$ using a dry combustion method with a Perkin Elmer $2400 \mathrm{CHN}$ analyser at the Centre of Tropical Marine Ecology, Bremen/Germany. Inorganic carbon was removed prior to the analysis by treatment with $1 \mathrm{~mol} . \mathrm{L}^{-1} \mathrm{HCl}$. Quantification was performed by using calibration curves and cystine as standard.

The extraction procedure for the analysis of sterols and ketones (in 19 out of 24 stations collected) followed the method described by Budzinski et al. (1999), using an open cell microwaveassisted and a Sox-wave apparatus. Aliquots of $3 \mathrm{~g}$ of freeze-dried sediments were extracted with a mixture of $30 \mathrm{~mL}$ of dichloromethane and $10 \mathrm{~mL}$ of Milli-Q water during $10 \mathrm{~min}$ at $30 \mathrm{~W}$ of power irradiation. The procedure was repeated two more times and the extracts combined. Before extraction, $5200 \mathrm{ng}$ of

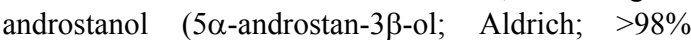
purity) were added to the sediments as surrogate and internal standard. The volume of the bulk extract was reduced by rotary evaporation under vacuum and gentle heating $\left(35^{\circ} \mathrm{C}\right)$. Residual water and elemental sulfur were removed from the extract by treatment with sodium sulfate and activated copper, respectively.

The detailed procedure for the isolation, identification and quantification of steroids can be found elsewhere (CARREIRA et al., 2004). In short, the steroid (alcohols and ketones) fraction was isolated from the bulk extract in a glass column ( $1 \mathrm{~cm}$ i.d., 15 $\mathrm{cm}$ height) filled with silica-gel and alumina $(5 \%$ water deactivated) by elution with $24 \mathrm{~mL}$ of a mixture of dichoromethane:methanol $(1: 9, \mathrm{v} / \mathrm{v})$. This fraction was concentrated by rotary evaporation and a gentle flux of purified $\mathrm{N}_{2}$ and derivatized with bis (trimethylsilyl)trifluoroacetamide (BSTFA) at $80^{\circ} \mathrm{C}$ for 1 hour before quantification.

The sterol fraction was analysed by highresolution gas chromatography (GC) using a HP 6890 gas chromatograph fitted with a split-less injector and a flame ionization detector (FID). An HP-5 capillary column (5\% phenyl-methyl-siloxane; $30 \mathrm{~m}$ length; 0.25 $\mathrm{mm}$ i.d. and $0.25 \mu \mathrm{m}$ film thickness) was used with Helium as the carrier gas at a constant flow rate of 1 $\mathrm{mL} \mathrm{min}^{-1}$. Injector temperature was set to $290^{\circ} \mathrm{C}$. The column temperature was programmed for a $1 \mathrm{~min}$ hold at $60^{\circ} \mathrm{C}$ and a ramp up to $300^{\circ} \mathrm{C}$ at $6^{\circ} \mathrm{C} \mathrm{min}^{-1}$, with a final hold of $29 \mathrm{~min}$.

Quantification was based on the response factor of each sterol relative to the internal standard ( $5 \alpha$-androstanol). Relative response factors were determined by the analysis in parallel of authentic standards of sterols, and for those compounds without standards available (see below) we used the response factor for the compound with similar retention time.

Sterols were identified (see Table 1) based on the retention times of authentic standards obtained in the GC/FID. For those compounds without commercial standards available (methylcoprostanol, brassicasterol and dinosterol) and/or not available in our lab (campesterol, campestanol, stigmastanol, $\beta$ sitostanol), peak identification and confirmation were done by GC/MS. Selected samples were injected in a Finnigan Trace GC/PolarisQ GC/MS system, using a DB5-MS capillary column (30 m length, $0.25 \mathrm{~mm}$ i.d. and $0.25 \mu \mathrm{m}$ film thickness) and splitless injection. Helium was used as the carrier gas at a constant flux of $1.2 \mathrm{ml} \mathrm{min}{ }^{-1}$. The column temperature was programmed from an initial 1-min hold at $60^{\circ} \mathrm{C}$, from $60^{\circ} \mathrm{C}$ to $290^{\circ} \mathrm{C}$ at $6^{\circ} \mathrm{C} \mathrm{min}^{-1}$ (hold for $20 \mathrm{~min}$ ) and then at $12^{\circ} \mathrm{C}$ to $305^{\circ} \mathrm{C}$, with a final hold of $5 \mathrm{~min}$. The injector was set to $250{ }^{\circ} \mathrm{C}$ and the transfer line to $300^{\circ} \mathrm{C}$. The MS detector operated in the EI $(70 \mathrm{eV})$ mode and in full scan (50-550 amu), with an acquisition rate of 6 scans $\mathrm{s}^{-1}$.

Typical recovery of the surrogate was in the range of $85-105 \%$, with a mean of $93.5 \pm 6.7 \%(n=$ 19). As $5 \alpha$-androstanol was used as surrogate and internal standard, all the results were automatically normalized to $100 \%$ recovery.

Data were subject to quality control procedures, like the analysis of spiked samples (3 replicates) and daily checks of the instrumental performance (response factors). Analyses of procedural blanks (6 replicates) indicated minor amounts of cholesterol and $\beta$-sitosterol, which were discounted from the real samples. Detailed information about these procedures can be found in Santos, (2001). The limits of quantification in Table 1 
were considered as the mean area of a peak with a minimum signal/noise ratio of 10 (obtained by successive dilution of standard solutions of sterols) and the mass $(3 \mathrm{~g})$ of sediment extracted.

Statistical Analisys

A principal component analysis (PCA) was performed considering all the 15 sterols quantified in
19 stations ( 5 stations did not contain data for sterols; see Table 2). Data were normalized following the method described in Yunker et al. (2005), which consists of dividing each variable by the sum of all variables, followed by division by the geometric mean of total sterol concentration in each station and logtransformation. PCA loadings (variables) and scores (cases) were project in a bi-dimensional plane in relation to Factor 1 and Factor 2.

Table 1. Sterols and ketones quantified in the sediments with their respective limits of quantification.

\begin{tabular}{|c|c|c|c|}
\hline Abbreviation & Steroidal compounds & Popular name & $\begin{array}{l}\text { Limit of quantification } \\
\left.\text { (ng. } \mathrm{g}^{-1}\right)\end{array}$ \\
\hline $\mathrm{S}_{1}$ & 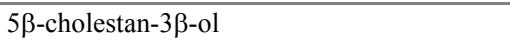 & Coprostanol & 0.03 \\
\hline $\mathrm{S}_{2}$ & $5 \beta$-cholestan- $3 \alpha$-ol & Epicoprostanol & 0.04 \\
\hline $\mathrm{S}_{3}$ & $5 \beta$-cholestan-3-ona & Coprostanone & 0.14 \\
\hline $\mathrm{S}_{4}$ & 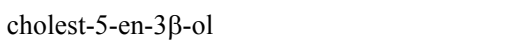 & Cholesterol & 0.04 \\
\hline $\mathrm{S}_{5}$ & $5 \alpha$-cholestan-3 $\beta$-ol & Cholestanol & 0.04 \\
\hline $\mathrm{S}_{6}$ & $5 \alpha$-cholestan-3 $\beta$-ona & Cholestanone & 0.06 \\
\hline $\mathrm{S}_{7}$ & 24 -methyl- $5 \beta$-cholestan-3 $\beta$-ol & Methylcoprostanol & - \\
\hline $\mathrm{S}_{8}$ & 24-methylcholesta-5,22-dien-3 $\beta$-ol & Brassicasterol & - \\
\hline $\mathrm{S}_{9}$ & 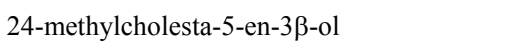 & Campesterol & - \\
\hline $\mathrm{S}_{10}$ & 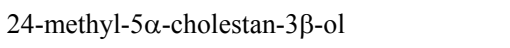 & Campestanol & - \\
\hline $\mathrm{S}_{11}$ & 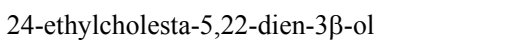 & Stigmasterol & 0.05 \\
\hline $\mathrm{S}_{12}$ & 24-ethyl-5,22-cholestan-3 $\beta$-ol & Stigmastanol & - \\
\hline $\mathrm{S}_{13}$ & 24-ethylcholesta-5-en-3 3 -ol & $\beta$-sitosterol & 0.05 \\
\hline $\mathrm{S}_{14}$ & 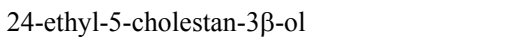 & $\beta$-sitostanol & - \\
\hline $\mathrm{S}_{15}$ & $4 \alpha, 23,24$-trimethyl- $5 \alpha$-cholesta-22-en- $3 \beta$-ol & Dinosterol & - \\
\hline
\end{tabular}

\section{Results AND Discussion}

\section{Total Organic Carbon and nNtrogen and $\mathrm{C} / \mathrm{N}$ Ratios of Surface Sediments}

Total organic carbon (TOC) ranged from 0.12 to $8.55 \%$ (Table 2$)$. Highest values $(7.20-8.55$ $\%$ were found at stations 8 and 16 , affected by effluents from a small fish processing factory in Jurujuba Bay and the Ary Parreiras Channel of Icaraí Bay, respectively. The majority of stations with siltclay sediments exhibited moderate to high concentrations of organic carbon (3.11 to $7.19 \%)$ and the sandy sediments of stations 4,17, 18, 19 and 24, the lowest organic carbon concentrations (Fig. 2-A). Total nitrogen (TN) contents of the sediments were highly correlated with organic carbon (Spearman; $r=$ $0.94 ; \mathrm{p}<0.05)$. The regression line between total nitrogen and total organic carbon $(\mathrm{TOC}=7.8 \mathrm{TN}+$ 0.42 , by weight) is close to zero, indicating that the adsorption of $\mathrm{NH}_{4}^{+}$on sediment particles was probably irrelevant.

The mean $\mathrm{C} / \mathrm{N}$ molar ratio of all sediments was rather uniform at $10.4 \pm 1.8$, did not allow clear distinctions between the contribution from natural (marine or terrestrial/riverine) and anthropogenic sources. The $\mathrm{C} / \mathrm{N}$ ratios lied within the common range of plankton material altered by microbial degradation and domestic effluents, without significant contribution form vascular plants materials. The carbon and nitrogen composition of the sediments indicated that the embayment may be classified as an organic-rich system similar to other eutrophic sectors of Guanabara Bay and coastal lagoons of the State of Rio de Janeiro, which are dominated by phytoplankton primary production favored by large excess of nutrients associated with domestic effluent inputs (CARREIRA et al., 2002; KNOPPERS et al., 1999; MEYERS; ISHIWATARI, 1993). 
Table 2. Total organic carbon (TOC), total nitrogen (TN), C/N ratio and sterols and ketones (individuals and total sum from $\mathrm{S}$ to $\mathrm{S}_{15}$; see Table 1 for names) in superficial $(0-5 \mathrm{~cm})$ sediments from Icaraí and Jurujuba Embayments. Values relative to dry sediment weight.

\begin{tabular}{|c|c|c|c|c|c|c|c|c|c|c|c|c|c|c|c|c|c|c|c|}
\hline 1 & 5.45 & 0.96 & 6.6 & 1.92 & 1.73 & 2.91 & 6.64 & 5.06 & 0.80 & 0.71 & 2.86 & 2.62 & 1.35 & 2.26 & 2.03 & 5.60 & 5.18 & 8.82 & 50.5 \\
\hline 2 & 6.84 & 0.84 & 9.5 & 7.72 & 5.34 & 8.23 & 6.55 & 13.7 & 1.99 & 2.10 & 5.42 & 4.08 & 3.65 & 5.94 & 4.98 & 14.5 & 11.9 & 26.5 & 122 \\
\hline 4 & 1.26 & 0.16 & 9.2 & na & na & na & na & na & na & na & na & na & na & na & na & na & na & na & na \\
\hline 5 & 6.92 & 0.83 & 9.7 & 0.94 & 2.51 & 7.59 & 5.03 & 7.84 & 1.65 & 0.21 & 2.53 & 2.95 & 3.45 & 7.13 & 5.39 & 9.66 & 12.2 & 17.2 & 86.2 \\
\hline 6 & 6.36 & 0.76 & 9.8 & 4.94 & 3.03 & 5.90 & 3.37 & 8.53 & 1.16 & 1.52 & 2.07 & 2.05 & 2.45 & 4.25 & 2.60 & 7.52 & 8.04 & 15.5 & 72.9 \\
\hline 7 & 7.19 & 0.86 & 9.8 & 1.67 & 1.61 & 2.76 & 3.61 & 3.22 & 0.87 & 1.14 & 1.42 & 1.24 & 0.90 & 1.80 & 1.79 & 3.15 & 5.84 & 6.3 & 37.3 \\
\hline 8 & 8.55 & 1.02 & 9.8 & 2.52 & 2.22 & 2.60 & 3.30 & 3.78 & 0.81 & 0.74 & 1.63 & 1.35 & 0.91 & 1.94 & 1.38 & 3.04 & 4.75 & 12.2 & 43.2 \\
\hline 11 & 5.32 & 0.59 & 10.5 & 2.60 & 1.61 & 3.42 & 2.98 & 3.37 & 0.66 & 0.65 & 1.48 & 0.96 & 0.77 & 1.05 & 0.95 & 2.80 & 3.69 & 5.22 & 32.2 \\
\hline 12 & 2.73 & 0.28 & 11.4 & 7.33 & 3.34 & 3.33 & 4.44 & 6.88 & 1.14 & 0.48 & 2.39 & 1.41 & 0.93 & 1.42 & 1.44 & 5.77 & 5.60 & 5.51 & 51.4 \\
\hline 13 & 2.04 & 0.16 & 14.9 & 3.91 & 2.68 & 2.77 & 5.78 & 6.11 & 0.89 & 0.51 & 1.45 & 1.07 & 0.73 & 1.08 & 0.85 & 4.98 & 4.28 & 1.81 & 38.9 \\
\hline 14 & 5.95 & 0.57 & 12.2 & 36.2 & 48.2 & 1.83 & 12.2 & 11.2 & 0.85 & 0.21 & 3.33 & 1.62 & 1.30 & 1.56 & 0.75 & 5.70 & 2.27 & 1.07 & 128 \\
\hline 15 & 6.11 & 0.55 & 13.0 & 2.93 & 3.17 & 2.10 & 2.37 & 5.44 & 0.78 & 0.43 & 0.94 & 0.47 & 0.53 & 0.93 & 0.61 & 2.30 & 3.66 & 1.73 & 28.4 \\
\hline 16 & 7.64 & 0.89 & 10.0 & 29.9 & 74.8 & 9.33 & 19.6 & 45.0 & 0.99 & 1.45 & 10.6 & 6.09 & 5.10 & 3.90 & 4.99 & 14.9 & 11.3 & 13.0 & 251 \\
\hline 17 & 0.17 & 0.02 & 9.9 & na & na & na & na & na & na & na & na & na & na & na & na & na & na & na & na \\
\hline 18 & 0.18 & 0.02 & 10.5 & na & na & na & na & na & na & na & na & na & na & na & na & na & na & na & na \\
\hline 19 & 0.13 & 0.02 & 7.6 & na & na & na & na & na & na & na & na & na & na & na & na & na & na & na & na \\
\hline
\end{tabular}
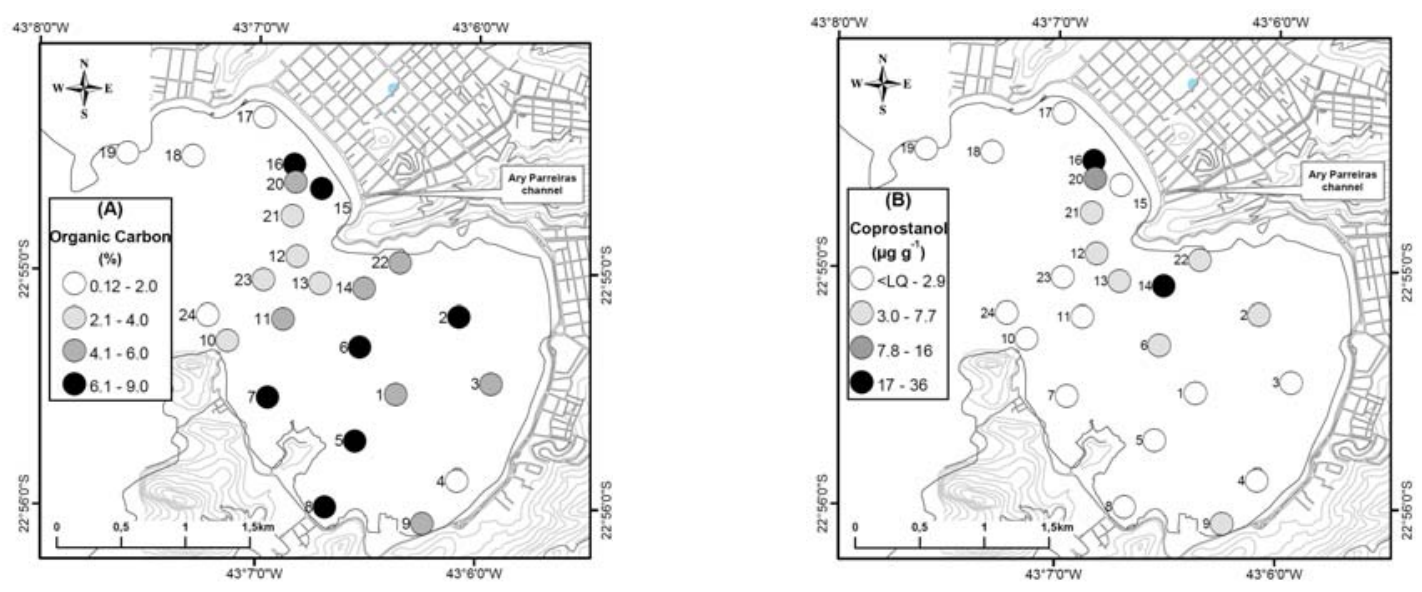

Fig. 2. Distribution of organic carbon (A) and coprostanol (B) in Icaraí and Jurujuba sounds superficial sediments. 
Autochthonous and Allochthonous Inputs of Organic Matter to the Surface Sediments

The steroidal biomarkers in the surface sediments revealed marked spatial variations in their concentrations and composition, enabling a more detailed evaluation of the contribution of organic matter from sewage and/or natural (marine and terrestrial/riverine) sources to the sediments than the bulk organic TOC and TN proxies.

In the present study, 15 steroidal compounds (alcohols and ketones) were identified (S1 to S15, Table 1). The total concentrations of steroids ranged from 7.41 to $251 \mu \mathrm{g} \mathrm{g}^{-1}$ (Table 2). Values below $20 \mu \mathrm{g}$ $\mathrm{g}^{-1}$ of total steroids were found at stations 10 and 23 , which are localized (Fig. 1) at the western limit of the sampling area close to those stations with sandy sediments and low organic carbon contents (St's 17, 18,19 and 24). Higher values of total steroids $(\geq 100$ $\left.\mu \mathrm{g} \mathrm{g}^{-1}\right)$ were found at stations $2,9,14,16$ and 20 , but differed with respect to the composition of individual compounds. For instance, station $16\left(251 \mu \mathrm{g} \mathrm{g}^{-1}\right.$ of total steroids) had a large contribution from coprostanol (S1), epicoprostanol (S2) and cholesterol (S5), while station $2\left(122 \mu \mathrm{g} \mathrm{g}^{-1}\right.$ of total steroids) contained mainly cholesterol (S5), $\beta$-sitosterol (S13) and dinosterol (S15).

It is interesting to observe that we didn't found significant correlation (Spearman coefficient, $\mathrm{p}$ $<0.05$ - data not shown) between total steroids and total organic carbon. These results highlight the existence of different sources of organic matter to the studied area, as discussed henceforth in further detail.

\section{Distribution of Sewage as Indicated by Fecal Sterols}

The concentration of coprostanol (S1, Table 2) in surface sediments from Icaraí and Jurujuba ranged from 0.64 to $36.24 \mu \mathrm{g} \mathrm{g}^{-1}$, with a mean of 3.98 $\mu \mathrm{g} \mathrm{g}^{-1}$. Elevated concentrations were found at stations 14,16 and 20, but not at station 15, which is the closest to the main point-source of the Ary Parreiras sewage channel (Fig. 2B). This suggests that the sewage material seems to have been transported in the water column both to the west along Icaraí beach and to the east into the Jurujuba sector, prior to its deposition on the sediments.

A general index for fecal contamination in the water column based on coprostanol and using bacterial counts as reference was proposed by several authors (ISOBE et al., 2004; ISOBE et al., 2002; LEEMING; NICHOLS, 1996). For sediments, however, there is much less information using the same approach (NICHOLS et al., 1993), since there are no guidelines for sediment contamination by sewage. In addition, the enhanced aerobic microbial degradation of coprostanol under elevated temperatures may lead to an underestimation of sewage contamination in tropical areas when compared to temperate systems subjected to the same level of environmental impact, as shown for Guanabara Bay (CARREIRA et al., 2004) and for a tropical estuary in NE Brazil (FERNANDES et al., 1999).

Since a quantitative index based on sterols cannot be easily established, as discussed above, one possible approach to evaluate the level of sewage contamination is to compare the concentration of coprostanol in our study area with data from other Brazilian coastal systems. As can be seen in Table 3, Guanabara Bay presents the highest concentrations of coprostanol in comparison to other regions, like Patos Lagoon, Santa Catarina Island, Ubatuba, Capibaribe Estuary and Sepetiba Bay, which is consistent with the higher load of sewage observed in Guanabara Bay (CARREIRA et al., 2004). Based on these data, we can consider that the stations close to the main discharge of sewage in Icaraí embayment (i.e., stations 14, 16 and 20; Table 2) are highly contaminated, while other regions in the studied area are low to moderately contaminated by fecal material.

In the assessment of sewage contamination, diagnostic index among selected sterols are usually considered together with the concentration of coprostanol (see a review in Takada et al., 1997). For example, values higher than 0.7 for the ratio between coprostanol and cholestanol $(5 \beta / 5 \beta+5 \alpha)$ stanol) were considered indicative of sewage contamination, whilst values $<0.3$ were found in uncontaminated sites (GRIMALT et al., 1990). In the present study, only at station 14 this ratio indicated contamination (Table 4), which is consistent with the maximum coprostanol concentration observed in that station $\left(36.2 \mu \mathrm{g} \mathrm{g}^{-1}\right)$.

On the other hand, in other stations with elevated concentrations of coprostanol $(7.3-29.9 \mu \mathrm{g}$ $\mathrm{g}^{-1}$; Table 2), intermediate values $(0.4-0.6)$ for the ratio $(5 \beta / 5 \beta+5 \alpha)$ stanol (Table 4$)$ were found. Similar results were observed in previous studies (CARREIRA et al., 2004; GRIMALT et al., 1990; READMAN et al., 2005). In these cases, Grimalt et al. (1990) proposed the ratio between coprostanone and cholestanone $\quad(5 \beta / 5 \beta+5 \alpha)$ stanone $), \quad$ because cholestanone is not produced by biological activity and ketones are, in general, less affected by degradation (SUN; WAKEHAM, 1998). In the present study, the concentrations of coprostanone $(0.82-9.3$ $\left.\mu \mathrm{g} \mathrm{g}^{-1}\right)$ were in the same range as those of coprostanol $\left(0.6-36.4 \mu \mathrm{g} \mathrm{g}^{-1}\right)$, but the concentration of cholestanone $\left(0.99 \pm 0.49 \mu \mathrm{g} \mathrm{g}^{-1}\right)$ was very low in comparison, for example, to cholestanol $(8.34 \pm 9.64$ $\left.\mu \mathrm{g} \mathrm{g}^{-1}\right)$. Consequently, the values for the ratio $(5 \beta / 5 \beta+5 \alpha)$ stanone were elevated $(0.79 \pm 0.06$; Table 4) and indicated contamination in all the studied area, which was not consistent with the distribution of coprostanol and/or coprostanone previously discussed. 
Table 3. Coprostanol in sediments from selected Brazilian coastal regions.

\begin{tabular}{|c|c|c|c|c|c|}
\hline \multirow{2}{*}{$\begin{array}{l}\text { Location } \\
\text { Patos Lagoon, Rio Grande do Sul } \\
\text { State }\end{array}$} & \multirow{2}{*}{$\begin{array}{c}\text { Sediment layer }(\mathrm{cm}) \\
0-2\end{array}$} & \multicolumn{3}{|c|}{ Concentration range $\left(\mu \mathrm{g} . \mathrm{g}^{-1}\right)$} & \multirow{2}{*}{$\begin{array}{c}\text { Reference } \\
\text { [Martins, 2007 \#1494] }\end{array}$} \\
\hline & & $<0.001 *$ & - & 0.92 & \\
\hline $\begin{array}{l}\text { Santa Catarina Island, Santa } \\
\text { Catarina State }\end{array}$ & $0-5$ & n.d** & - & 2.88 & [Mater, 2004 \#1341] \\
\hline $\begin{array}{l}\text { Northen coastal area of São Paulo } \\
\text { State }\end{array}$ & $0-15$ & 0.02 & - & 5.90 & [Kawakami, 1999 \#424] \\
\hline Ubatuba Region, São Paulo State & $0-3$ & $<0.01 *$ & - & 0.27 & [Muniz, 2006 \#1495] \\
\hline $\begin{array}{l}\text { Capibaribe River (city of Recife), } \\
\text { Pernambuco State }\end{array}$ & $0-3$ & 0.52 & - & 7.30 & [Fernandes, $1999 \# 372]$ \\
\hline Sepetiba Bay, Rio de Janeiro State & $0-2$ & 0.08 & - & 0.42 & Carreira, 2005 - not published \\
\hline Northen Guanabara Bay & $0-3$ & 0.33 & - & 40.0 & [Carreira, 2004 \#1149] \\
\hline South-western Guanabara Bay & $0-2$ & 1.38 & - & 105 & [Costa, $2005 \# 1389]$ \\
\hline South-eastern Guanabara Bay & $0-5$ & 0.64 & - & 36.2 & This study \\
\hline
\end{tabular}

*limit of detection; **n.d. $=$ non detected

Table 4. Ratios among selected sterols in superficial $(0-5 \mathrm{~cm})$ sediments from Icaraí and Jurujuba Embayments.

\begin{tabular}{cccc}
\hline \hline Stations & coprostanol/cholesterol & $(5 \beta / 5 \beta+5 \alpha)$ stanol & $(5 \beta / 5 \beta+5 \alpha)$ stanone* \\
\hline 1 & 0.29 & 0.28 & 0.78 \\
2 & 1.18 & 0.36 & 0.81 \\
3 & 0.66 & 0.37 & 0.78 \\
4 & 0.19 & 0.11 & 0.82 \\
5 & 1.47 & 0.37 & 0.84 \\
6 & 0.46 & 0.34 & 0.76 \\
7 & 0.76 & 0.40 & 0.76 \\
8 & 0.44 & 0.27 & 0.75 \\
9 & 0.28 & 0.57 & 0.85 \\
10 & 0.87 & 0.44 & 0.84 \\
11 & 1.65 & 0.52 & 0.74 \\
12 & 0.68 & 0.39 & 0.76 \\
13 & 2.96 & 0.76 & 0.68 \\
14 & 1.24 & 0.35 & 0.73 \\
15 & 1.52 & 0.40 & 0.90 \\
16 & 1.97 & 0.58 & 0.82 \\
17 & 2.28 & 0.55 & 0.63 \\
18 & 1.25 & 0.49 & 0.83 \\
19 & 1.37 & 0.55 & 0.83 \\
20 & 0.29 & 0.28 & 0.78 \\
21 & 1.18 & 0.36 & 0.81 \\
22 & 0.66 & 0.37 & 0.78 \\
23 & 0.19 & 0.11 & 0.82 \\
24 & 1.47 & 0.37 & 0.84 \\
\hline$*(5 \beta / 5 \beta+5 \alpha)$ stanol & coprostanol/(coprostanol+cholestanol); & $5 \beta / 5 \beta+5 \alpha)$ stanone
\end{tabular}

= coprostanone $/$ (coprostanone/cholestanone). 
The ratio coprostanol/cholesterol is another usual index, with values higher than 1.0 associated with high levels of sewage contamination (FATTORE et al., 1996; QUÉMÉNEUR \& MARTY, 1992; 1994; TAKADA et al., 1994). The mean value for this ratio in the present study was 1.13 , but ranged between 0.19 and 2.96 (Table 4).

There was a good correlation $\left(\mathrm{r}^{2}=0.80 ; \mathrm{p}<\right.$ 0.0001 ) between the ratios coprostanol/cholesterol and $(5 \beta / 5 \beta+5 \alpha)$ stanol (Fig. 3) for all stations, except stations 5 and 10 (not included in the model). Station 5 was not contaminated by sewage, but the low value in the $\mathrm{X}$ axis for this station in Figure 3 was due to high concentration of cholesterol, similar to the nearby stations 1 and 6. Station 10, on the other hand, had low concentrations of both coprostanol and cholestanol, which might have influenced in the comparison of the ratios considered.

It is interesting to observe in Figure 3 that values around 1.0 for the ratio coprostanol/cholesterol (indicative of contamination) correspond to around $0.4-0.5$ for the ratio $5 \beta /(5 \beta+5 \alpha)$ stanol (Fig. 3). Thus, the data of the present work support the suggestion of using a lower threshold $(\geq 0.5)$ for the ratio
$5 \beta /(5 \beta+5 \alpha)$ stanol when evaluating the sewage contamination in tropical euthrophic systems (CARREIRA et al., 2004; ISOBE et al., 2002). In addition, the good correlation between the ratios coprostanol/cholesterol and $5 \beta /(5 \beta+5 \alpha)$ stanol indicated that the biogenic input of cholestanol is more important than the diagenetic production of cholesterol in altering the Grimalt's ratio.

Another major feature in the distribution of the faecal sterols is the relatively high concentration of epicoprostanol (Table 2). Epicoprostanol is not a major human fecal sterol and is therefore found at low concentrations in areas contaminated by raw domestic sewage (MUDGE; LINTERN, 1999). During extensive anaerobic sewage treatment, however, epicoprostanol may be produced from cholesterol (McCALLEY et al., 1981). In the present study, the concentration of epicoprostanol in stations 14, 16 and 20 was higher than that of coprostanol (Table 2), which is consistent with the fact that the bulk sewage receives some kind of treatment before disposal in the Icaraí and Jurujuba embayments.

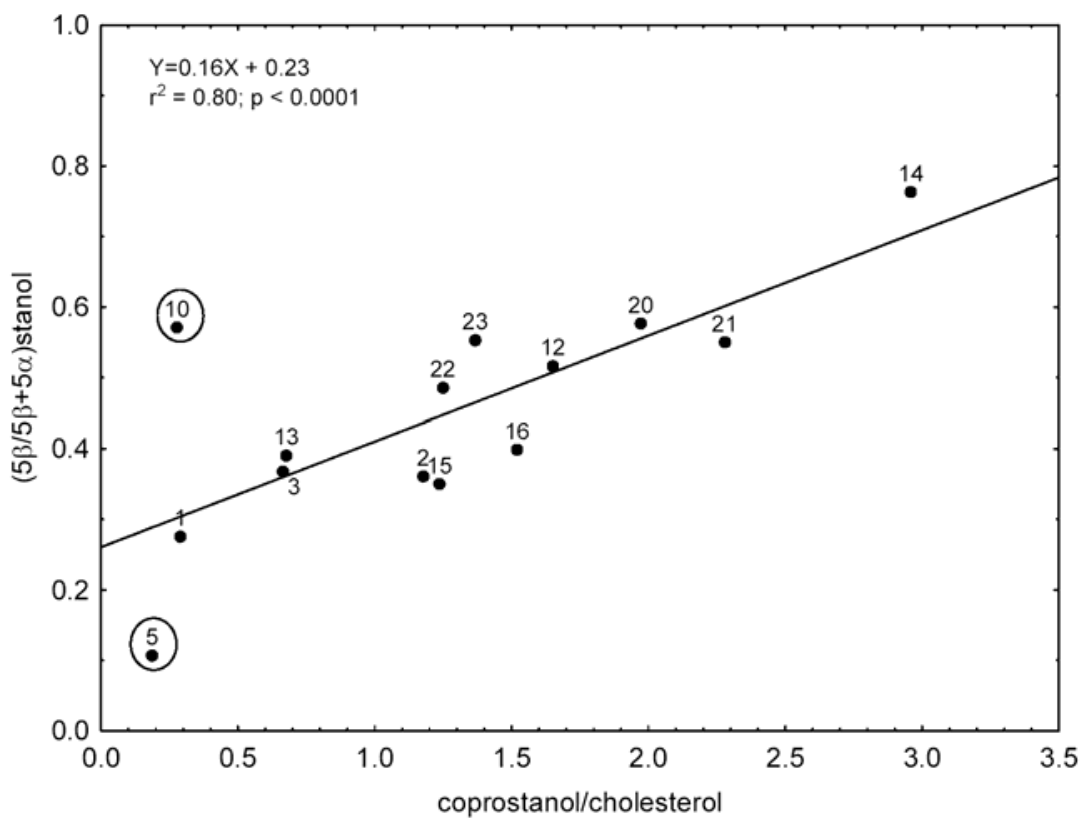

Fig. 3. Comparison of the ratios $(5 \beta / 5 \beta+5 \alpha)$ stanol and coprostanol/cholesterol. Linear fit considering all sediment samples is indicated by a black line. Stations 5 and 10 (marked with a circle) were not included in the model (see text for details).

\section{Contribution of Natural Sources of Organic Matter}

The relative contribution of distinct sources of organic matter can be assessed by grouping specific sterols as follows (modified from Mannino and Harvey, 1999; Tolosa et al., 2003): (i) zooplankton/phytoplankton: cholesterol and cholestanol; (ii) algae: brassicasterol (24- 
methylcholest-5,22-dien-3 $\beta$-ol)) and dinosterol $(4 \alpha-$ 23,24 -trimethyl- $5 \alpha$-cholest-22-en-3 $\beta$-ol); (iii) higher plants/algae: campesterol (24-methylcholest-5-en-3 $\beta$ ol), stigmasterol (24-ethylcholest-5,22-dien-3 $\beta$-ol) and $\beta$-sitosterol (24-ethylcholest-5-en-3 $\beta$-ol) and (iv)

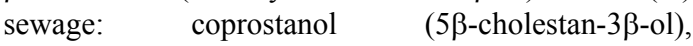

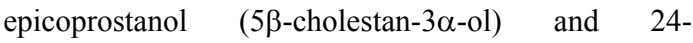
methylcoprostanol (24methyl-5 $\beta$-cholestan-3 $\beta$-ol). The results obtained for each station on the basis of sediment mass weight and organic carbon content are shown in Figure 4.

The approach of grouping sterols only indicates an overall trend of the relative contributions of distinct sources of organic matter, because it is limited to the specific compounds identified in the present work. Despite this limitation, in Figure 4 it is possible to observe two characteristics in the distribution of sedimentary organic matter in the studied area: (i) a higher proportion of sewage in Icaraí (stations 15 to 24) than in Jurujuba (stations 1 to 9); (ii) the fraction of algae-derived organic matter is more important in Jurujuba than in Icaraí.

The principal individual sterol in the "algae group" was dinosterol (5.9 to $26.50 \mu \mathrm{g} \mathrm{g}^{-1}$; Table 2). This sterol is a known marker for dinoflagellates and to a lesser extent some groups of diatoms (VOLKMAN et al., 1998). Brassicasterol, the other algae-derived sterol in the present study, is associated with inputs from diatoms (VOLKMAN et al., 1998), but this sterol was present at low concentrations (0.89 to $\left.5.52 \mu \mathrm{g} \mathrm{g}^{-1}\right)$ in both embayments.

The distribution of "higher plant/algae group" (campesterol, stigmasterol and $\beta$-sitosterol) showed a slight tendency to high values at stations 2,5 and 9 (Fig. 4). This indicated the input of riverderived organic material to Jurujuba, but the sourcespecificity of these compounds to terrestrial/riverine organic matter assignments is still being questioned (VOLKMAN et al., 1999; ZIMMERMAN; CANUEL, 2000). To overcome this limitation, it was proposed to evaluate the ratio campesterol/stigmasterol/ $\beta$ sitosterol: values close to $1 / 1.6 / 6.6$ would be associated with a terrestrial/riverine source while lower ratios suggest a marine phytoplankton source for these compounds (LAUREILLARD; SALIOT, 1993; VOLKMAN, 1986). In the present work, the average value of 1/1.5/2.8 indicates that stigmasterol had a riverine/terrestrial origin, but the low value for $\beta$ sitosterol could be associated with autochthonous sources for this compound (this point will be discussed further in the next section).

\section{Statistical Analysis}

Principal component analysis (PCA) with the sterol data was performed as an additional tool in the evaluation of the sources of organic matter to the studied area. A bi-dimensional (unrotaded) plot of loadings (variables) and scores (samples) for factors 1 and 2 obtained from the PCA modeling is presented in Figure 5. Factor 1 accounted for $44.1 \%$ of total data variance, and allowed a reasonable resolution between sterols derived from sewage (coprostanol and epicoprostanol), with positive loadings, and "natural" sterols (marine or terrestrial/riverine), that contributed negatively, in most cases, to this factor. Factor 2 accounted for only $20.3 \%$ of total variance, but resulted in positive values for cholesterol (S5), brassicasterol (S8), campesterol (S9) and dinosterol (S15), and negative values for stigmasterol (S11) and $\beta$-sitosterol (S13), as well as for their saturated homologues (stigmastanol and $\beta$ sitostanol).

The PCA model grouped stigmasterol and $\beta$ sitosterol and separated them from campesterol, which in turn was closely related with other algalderived sterols (Fig. 5-A), indicating a riverine/terrestrial origin for $\beta$-sitosterol. This result is opposite to that obtained by the ratio campesterol:stigmasterol: $\beta$-sitosterol (see discussion in section 3.2.2), indicating that this ratio cannot be used in the present study.

The position of the samples (scores) in the PCA model confirmed that Icaraí and Jurujuba embayments were influenced by different sources of organic matter. Positive values for factor 1 (sewage influence) were observed for those stations close to the Ary Parreiras Channel, in Icaraí (Fig. 5-B), where higher concentrations of coprostanol were measured (stations 14, 16 and 20, and to a lesser extent stations $12,13,15$ and 21). On the other hand, all the stations from Jurujuba contributed negatively to factor 1 , indicating higher influence of autochthonous sources of organic matter in this region. Probably, the nutrients delivered by local contaminated rivers, coupled with restricted water circulation, supports autochthonous primary production and enhanced accumulation of the recently-produced organic material in Jurujuba sediments.

Historic Record of Recent Sedimentation of Organic Matter

The short sediment core for the reconstruction of natural and cultural impacts was taken in Jurujuba embayment, because it is more enclosed, contains more organic-rich fine sediments and is more eutrophic than the Icarai embayment (NETTO et al., 2000; SANTOS, 2001). The sediment core exhibited three distinct phases in accordance to the concentrations and composition of organic matter and sterols (Table 5; Fig. 6). 

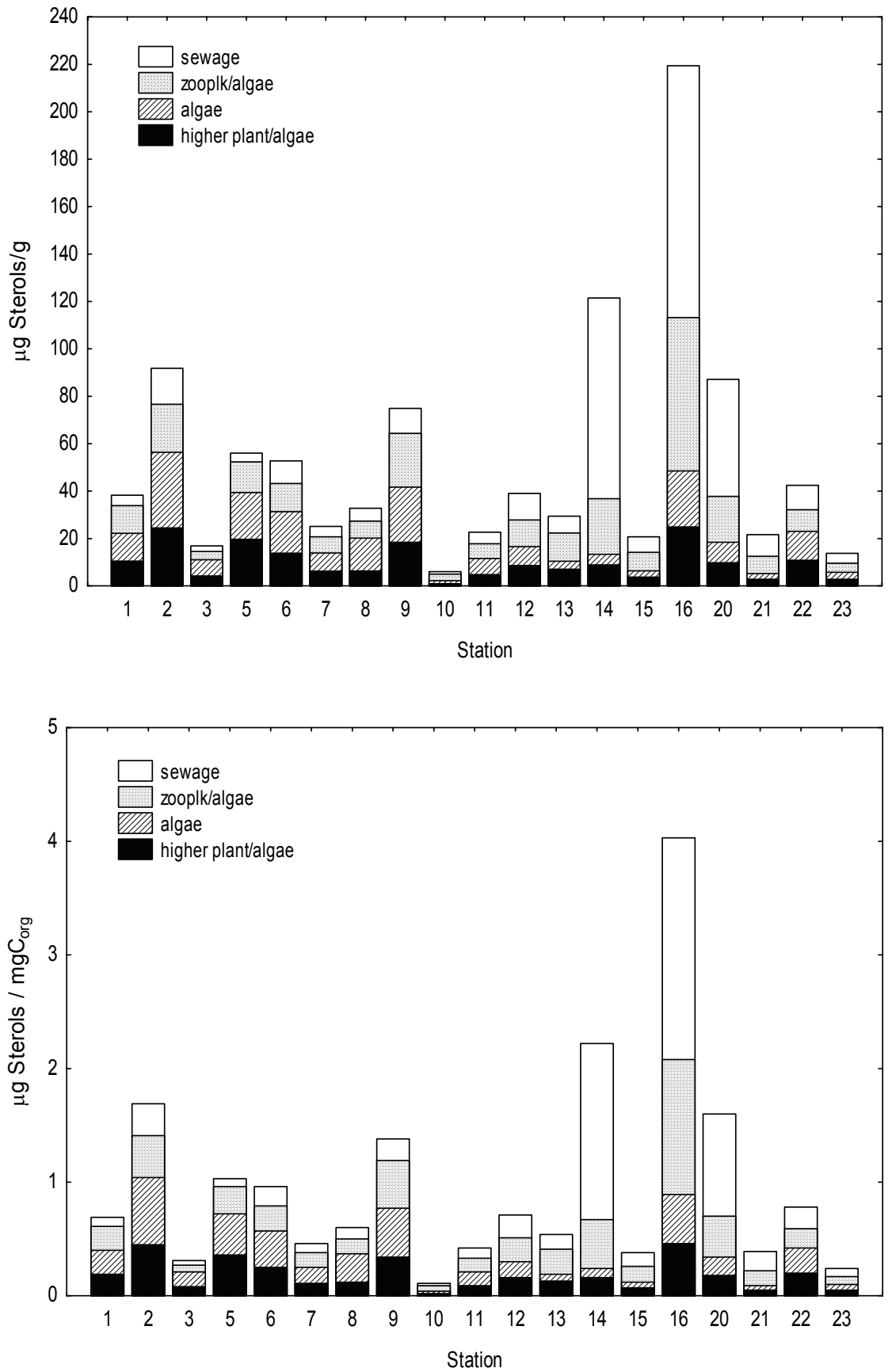

Fig. 4. Source classification of sterols in sediments from Icaraí e Jurujuba embayments. Higher plants and/or algae: 24-methylcholesta-5-en-3 $\beta$-ol, 24-ethylcholesta-5,22-dien-3 $\beta$-ol, 24-ethylcholesta-5-en-3 $\beta$-ol; Algae:

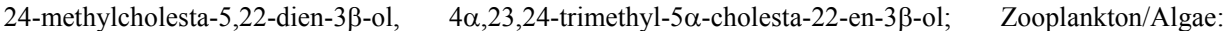

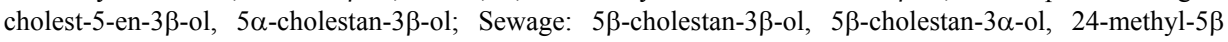
cholestan-3 $\beta$-ol. See text for more details. 

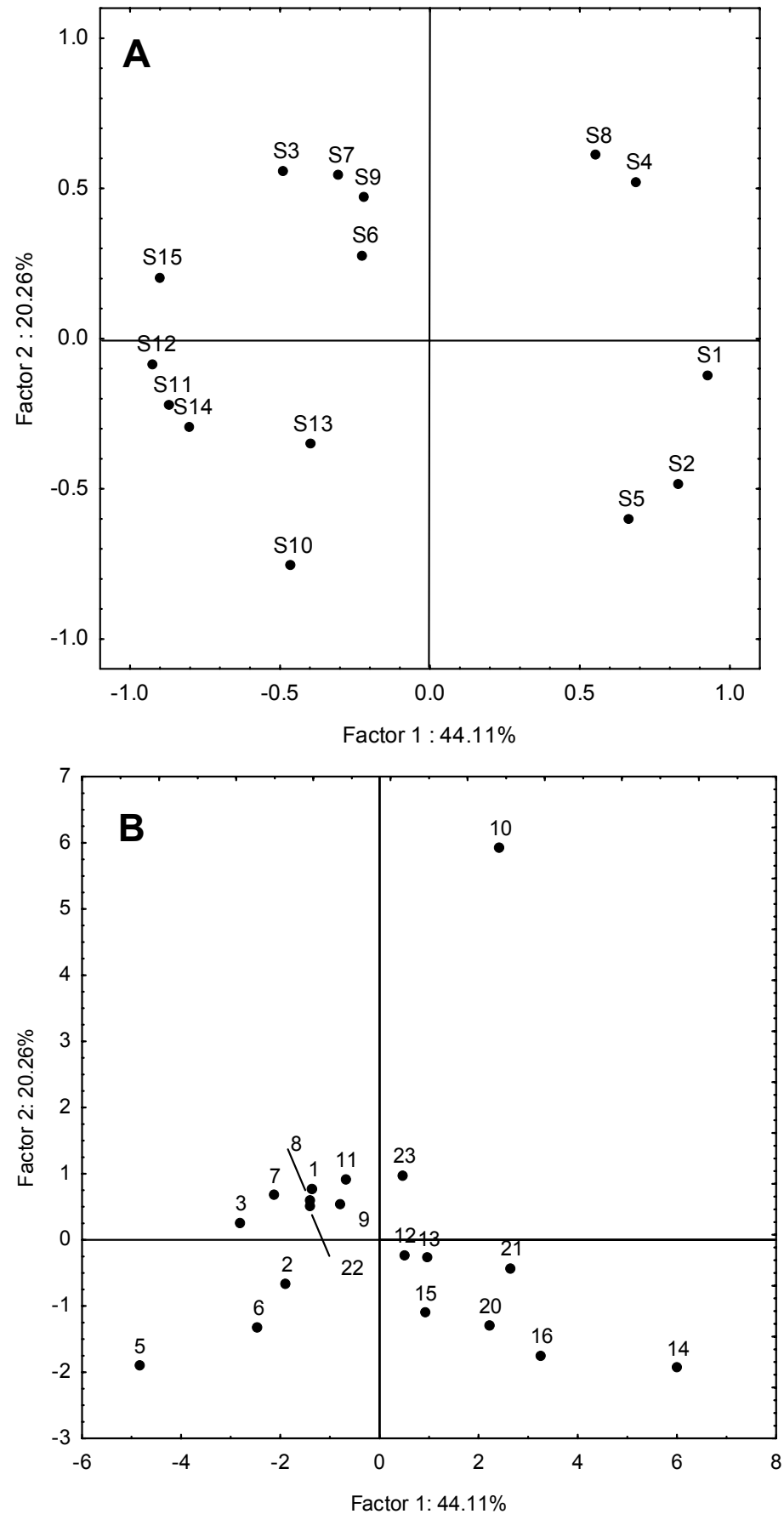

Fig. 5. Plot of the loading (variables; upper panel) and scores (stations; lower panel) on the bi-dimensional plane represented by factor 1 and factor 2 in PCA analysis. Codes for sterols is the same as in Table 1. 
Table 5. Total organic carbon (TOC), total nitrogen $(\mathrm{TN}), \mathrm{C} / \mathrm{N}$ ratio and sterols (individuals and total sum from $\mathrm{S}_{1}$ to $\mathrm{S}_{15}$; see Table 1 for names) in a sediment core collected at station 1 . Values relative to sediment dry-weight.

\begin{tabular}{|c|c|c|c|c|c|c|c|c|c|c|c|c|c|c|c|c|c|c|c|}
\hline $\begin{array}{l}\text { Mean } \\
\text { depth } \\
(\mathrm{cm})\end{array}$ & $\begin{array}{l}\text { TOC } \\
(\mathrm{cm})\end{array}$ & $\begin{array}{l}\text { TN } \\
(\%)\end{array}$ & $\underset{\text { (molar) }}{\mathrm{C} / \mathrm{N}}$ & $\mathrm{S}_{1}$ & $\mathrm{~S}_{2}$ & $\mathrm{~S}_{3}$ & $\mathrm{~S}_{4}$ & $\mathrm{~S}_{s}$ & $\mathrm{~S}_{6}$ & $\begin{array}{c}\mathrm{S}_{7} \\
\left(\mu \mathrm{g} \mathrm{g}^{-1}\right)\end{array}$ & $\mathrm{S}_{8}$ & $\mathrm{~S}_{9}$ & $\mathrm{~S}_{10}$ & $\mathrm{~S}_{11}$ & $\mathrm{~S}_{12}$ & $\mathrm{~S}_{13}$ & $\mathrm{~S}_{14}$ & $\mathrm{~S}_{15}$ & Total \\
\hline 0.5 & 5.45 & 0.96 & 6.61 & 1.92 & 1.73 & 2.91 & 6.64 & 5.06 & 0.81 & 0.70 & 2.86 & 2.62 & 1.35 & 2.26 & 2.02 & 5.59 & 5.18 & 8.82 & 50.47 \\
\hline 4.0 & 5.31 & 0.91 & 6.81 & 3.09 & 1.78 & 3.51 & 4.65 & 5.32 & 0.93 & 0.69 & 2.43 & 2.09 & 1.49 & 1.67 & 2.02 & 4.22 & 6.11 & 9.60 & 49.6 \\
\hline 6.5 & 4.7 & 0.75 & 7.29 & 3.61 & 2.41 & 2.53 & 4.85 & 2.22 & 1.81 & 2.08 & 1.88 & 2.00 & 2.21 & 3.54 & 3.19 & 6.32 & 10.36 & 11.83 & 60.84 \\
\hline 15.5 & 4.48 & 0.71 & 7.37 & 0.54 & 1.06 & 2.94 & 1.26 & 1.78 & 0.85 & 0.40 & 1.55 & 1.13 & 1.07 & 1.82 & 1.69 & 2.96 & 5.06 & 10.25 & 34.36 \\
\hline 18.5 & 4.74 & 0.74 & 7.50 & 0.36 & 0.53 & 1.22 & 0.69 & 1.38 & 0.81 & n.d. & 1.04 & 0.69 & 0.91 & 1.37 & 1.46 & 2.26 & 4.56 & 10.50 & 27.78 \\
\hline 21.5 & 4.21 & 0.63 & 7.75 & 0.30 & 0.36 & 1.44 & 0.78 & 1.24 & 0.85 & n.d. & 1.20 & 0.85 & 1.07 & 1.22 & 1.31 & 1.59 & 7.37 & 15.95 & 35.53 \\
\hline 24.5 & 4.21 & 0.63 & 7.80 & 0.09 & 0.20 & 1.35 & 0.93 & 0.97 & 0.78 & n.d. & 1.31 & 0.61 & 0.71 & 0.88 & 1.58 & 1.95 & 5.60 & 8.33 & 25.29 \\
\hline 33.5 & 4.06 & 0.6 & 7.88 & 0.19 & 0.38 & 2.08 & 0.68 & 0.86 & 0.58 & n.d. & 0.66 & 0.59 & 0.55 & 0.68 & 1.08 & 1.78 & 3.86 & 5.95 & 19.92 \\
\hline 36.5 & 3.43 & 0.49 & 8.14 & 0.23 & 0.44 & 3.28 & 0.60 & 0.74 & 0.58 & n.d. & 0.42 & 0.82 & 0.73 & 1.05 & 1.07 & 1.52 & 4.76 & 6.42 & 22.66 \\
\hline 39.5 & 3.33 & 0.47 & 8.33 & 0.18 & 0.47 & 2.36 & 0.35 & 0.57 & 0.41 & 0.22 & 0.19 & 0.51 & 0.42 & 0.41 & 0.61 & 0.84 & 3.05 & 5.66 & 16.25 \\
\hline 42.5 & 3.33 & 0.46 & 8.38 & 0.36 & 0.89 & 2.40 & 0.54 & 1.04 & 0.65 & 0.13 & 0.18 & 0.83 & 0.55 & 0.64 & 1.22 & 2.04 & 4.78 & 11.40 & 27.65 \\
\hline
\end{tabular}

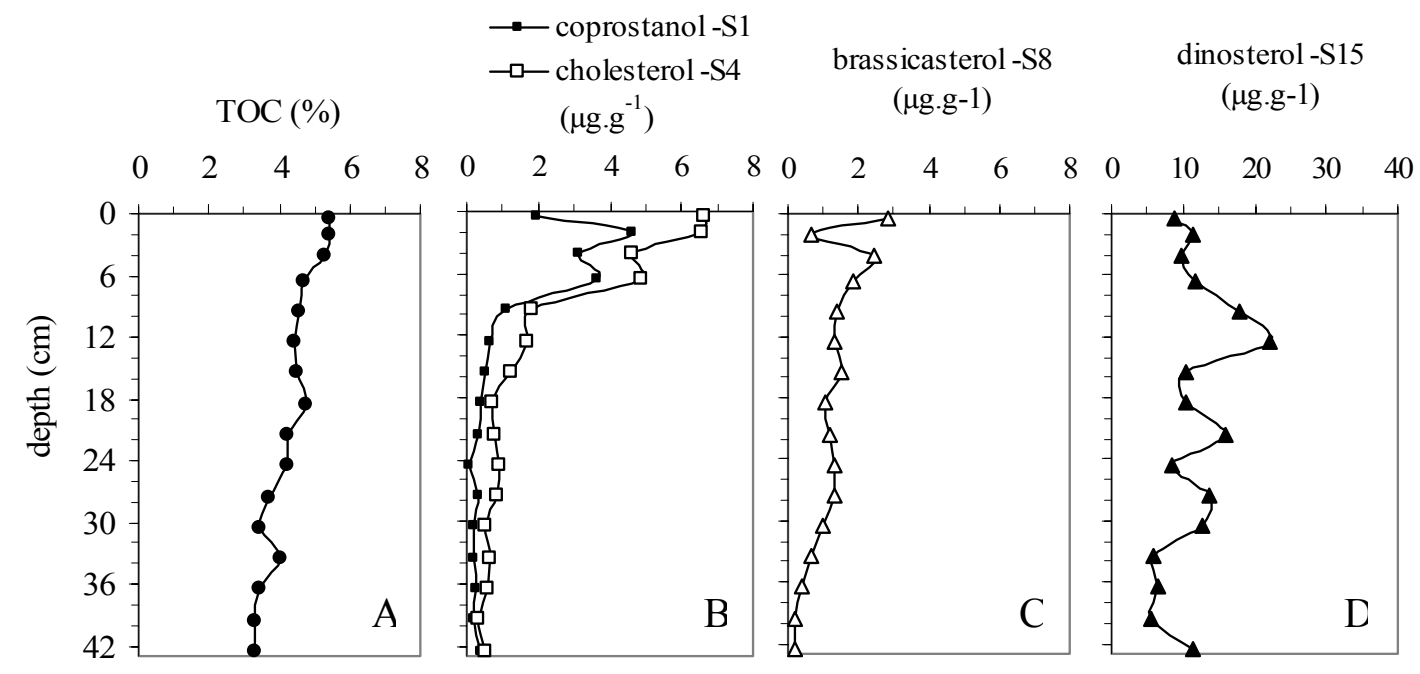

Fig. 6. Profile of TOC and selected sterols in the sediment core in Jurujuba sound.

The first layer, from the surface down to about $6.5 \mathrm{~cm}$ depth, presented a slight increase in organic carbon (Fig. 6-A), C:N values (6.6 to 7.3) typical of phytoplankton (MEYERS, 1997; REDFIELD et al., 1963), and highest concentrations of the sewage marker coprostanol (2 to $4.6 \mu \mathrm{g} \mathrm{g}^{-1}$, Fig. 6-B) and cholesterol (4.7 to $6.6 \mu \mathrm{g} \mathrm{g}^{-1}$, Fig. 6-B). Other sterols, like brassicasterol (0.7 to $2.9 \mu \mathrm{g} \mathrm{g}^{-1}$; Fig. 6-C) and cholestanol (2.2 to $\left.5.5 \mu \mathrm{g} \mathrm{g}^{-1}\right)$ also showed increased concentrations in the first $6.5 \mathrm{~cm}$ layer of the core, but the same was not observed for dinosterol (Fig. 6-D). A transition zone in the core was observed between 9.5 and $12.5 \mathrm{~cm}$ depth, which is characterized by a marked decline in concentration of many sterols (Figs. 6B and 6C), except for stigmasterol, $\beta$-sitosterol and dinosterol (Table 5, Fig.6D). Finally, a deeper downcore phase, between 18.5 and $45.5 \mathrm{~cm}$ depth, was characterized by a leveling out of TOC from 4.7 to 
$3.3 \%$, increasing $\mathrm{C}: \mathrm{N}$ ratios from 7.5 to 8.1 , and lowest relatively constant "background" concentrations of the majority of sterols, when compared to other studies in Guanabara Bay (CARREIRA et al., 2002).

In spite of the distinct phases described above, TOC and total steroids concentrations in the core samples were highly correlated $(\mathrm{r}=0.76 ; \mathrm{p}<$ $0.01 ; \mathrm{n}=17$ ). This result indicated that, contrary to what was observed in the surface sediments due to multiple sources of organic matter (see previous discussion), the total steroid accumulation in the sediment core was controlled by organic matter deposition.

The depth profile variation in the concentration of dinosterol showed various peaks along the core and higher values at the transition phase (Fig. 6-D). On the other hand, and contrary to expectations, brassicasterol was at much lower concentrations and did not follow the same pattern of dinosterol, particularly downwards of $18.5 \mathrm{~cm}$ depth. Based on the distribution of these two algal sterols, it seems that in Jurujuba embayment occurred temporal events of phytoplankton blooms composed largely of dinoflagellates, while diatoms played a minor role in the production of organic matter in the studied area. This hypothesis is preliminary and needs to be confirmed by the distribution of other molecular markers, especially fatty acids.

Another important feature in the distribution of individual sterols in the core are the elevated values for different stenol/stanol ratios, like cholestanol/cholestanol, campestanol/campesterol, stigmastanol/stigmasterol and $\beta$-sitostanol $/ \beta$-sitosterol. All ratios showed values between 1.0 and 2.0 with minor variations over depth, except for the ratio $\beta$ sitostanol $/ \beta$-sitosterol (Table 5). Probably, bacterial activity and grazing in the water column and within the nepheloyd layer of the surface sediments affected the composition of these sterols prior to their accumulation in the sediments.

The influence of sewage derived organic matter in the top layer becomes more evident when coprostanol concentrations are normalized to TOC. The maximum of $85.70 \mathrm{ng} \mathrm{gCorg}^{-1}$ was observed at 2 $\mathrm{cm}$ depth of the core, with an accentuated decrease down to $9.5 \mathrm{~cm}$ and $18.5 \mathrm{~cm}$ depths, with 21.97 and $7.62 \mathrm{ng} \mathrm{gCorg}^{-1}$, respectively, and the concentrations around $6.31 \pm 2.41 \mu \mathrm{g} \mathrm{gCorg}^{-1}$ down in the core. The concentrations for the deeper sediment layers were lower than those previously observed for Guanabara Bay (CARREIRA et al., 2002) and other coastal systems in the world (JENG; HAN, 1996; VENKATESAN; KAPLAN, 1990). If the deposition of sewage kept in pace with that of organic carbon, the normalized concentration of the faecal sterol would have remained constant.
Unfortunatelly, the exact period reflecting the beginning of sewage impact in the Jurujuba embayment cannot be estimated due to the lack of sedimentation rate analysis in the core. However, the trend of demographic expansion of the city of Niterói indicates that an increase of sewage derived input of nutrients must have affected the studied region. According to statistical census data of IBGE (www.ibge.gov.br), the population of Niterói expanded largely by about 250,000 inhabitants between the 1940's and 1980's and, henceforth, at a slower pace, with an addition of 60,000 inhabitants until the early 2000. Mechanical treatment of the effluents started in the 80's and the sewage outfall diverting effluents from the embayments to the central channel of Guanabara Bay initiated in 2000.

The environmental contamination of Icarai and Jurujuba embayments is now in direct conflict with fishing activities, which employ about 2000 people in Jurujuba embayment. Environmental legislation and the Guanabara Bay Pollution Mitigation Program (http://www.cibg.rj.gov.br) account for remedial actions and monitoring of the system. However, the program only envisages conventional analysis of coliforms and other standard water quality properties, which only allow for momentary assessments instead of the medium to long-term reconstruction of sewage impacts. This and other studies in Guanabara Bay revealed the necessity for the incorporation of anthropogenic molecular markers as a standard method for impact assessment in the system, which are, however, costlier to analyze than some of the standard methods (TAKADA; EGANHOUSE, 1998). The cost factor may be drastically reduced, when considering only coprostanol, which revealed to be good marker for sewage impacts in all studies performed in Guanabara Bay (CARREIRA et al., 2002).

\section{Conclusions}

In the present study it was possible to identify some relevant natural and anthropogenic processes that influence the distribution of organic matter in the Icarai and Jurujuba embayments. Coprostanol concentrations revealed, when compared to other regions in Guanabara Bay, higher contamination by sewage close to the point of sewage discharge in Icaraí Icaraí embayment, which operated until 2000. In Jurujuba sediments, the sewage-derived organic matter was less important.

The ratio $5 \beta /(5 \beta+5 \alpha)$ stanol, commonly used to evaluate the level of sewage contamination, when compared to other ratios and absolute coprostanol concentrations, indicated sewage contamination at lower values than those found for temperate systems. These discrepancies between tropical and temperate 
systems were already observed in other studies in Guanabara Bay, and may be derived from enhanced bacterial degradation of coprostanol under warmer conditions.

In Jurujuba embayment, the sediments are characterized by a high proportion of phytoplankton derived organic matter. Autochthonous production of organic matter fuelled by the discharge of nutrients from runoff and internal recycling, and subsequent eutrophication, seems to be enhanced by the restricted water circulation of the bay.

In the sedimentary record, the higher values of coprostanol and, particulary, its carbon-normalized concentrations in the more recent sediment layers, indicated an increase in the accumulation of sewage particles in the region, affecting the environmental quality of the sediments. In addition, the increase in algal-derived sterols and sewage derived coprostanol in the core, associated with information on demographic expansion, suggests that accelerated cultural eutrophication initiated in the mid-50's.

\section{ACKNOWLEDGMENTS}

The author thanks the suggestions from an anonymous reviewer, which greatly improved the final version of the manuscript. This work was supported by a reasearch grant from FAPERJ (Fundação de Amparo à Pesquisa do Estado do Rio de Janeiro) and a M.Sc. Grant to E. Sabadini-Santos from CNPq (Conselho Nacional de Desenvolvimento Científico e Tecnológico). R. Carreira and B. Knoppers are $\mathrm{CNPq}$ research fellows.

\section{REFERENCES}

BAPTISTA-NETO, J. A., SMITH, B.J. ; MCALLISTER, J. J. Sedimentological evidence of human impact on a neashore environment: jurujuba sound, Rio de Janeiro State, Brazil. Appl. Geochem., v. 19, p. 155-177, 1999.

BAPTISTA-NETO, J.A.; SMITH, B. J.; MCALLISTER, J. J. 2000. Heavy metal concentrations in surface sediments in a neashore environment, Jurujuba Sound, southeast Brazil. Environ. Pollut., v. 109, p. 1-9, 1999.

BARTLETT, P.D. Degradation of coprostanol in an experimental system. Mar. Pollut. Bull., v. 18, n. 1, p. 27-29, 1987

BUDZINSKI, H., LETELLIER, M., GARRIGUES, P.; LE MENACH, K. J. Microwave-assisted extraction in open cell of polycyclic aromatic hydrocarbons from soils sediments study of moisture effect. J. Chromatog., v. 837, p. 187-200, 1999.

CANUEL, E. A. Relations between river flow, primary production and fatty acid composition of particulate organic matter in San Francisco and Chesapeake Bays: a multivariate approach. Org. Geochem., v. 32, p. 563583,2001
CARREIRA, R. S.; WAGENER, A. L. R.; FILEMAN, T.; READMAN, J.; MACKO, S.A.; VEIGA, A. Changes in sedimentary organic carbon pool of a fertilized tropical estuary, Guanabara Bay, Brazil: an elemental, isotopic and molecular marker approach. Mar. Chem., v.79, n. 34, p. 207-227, 2002.

CARREIRA, R. S.; WAGENER, A. L. R.; READMAN, J. W. Sterols as markers of sewage contamination in a tropical urban estuary (Guanabara Bay, Brazil): spacetime variations. Estuar. coast Shelf Sci., v. n. 60, n. 4, p. 587-598, 2004.

CHALAUX, N.; TAKADA, H.; BAYONA, J. M. Molecular markers in Tokyo Bay sediments: sources and distribution. Mar. environ. Res., v. 40, n. 1, p. 77-92, 2002.

COUNTWAY, R.E.; CANUEL, E.A.; DICKHUT, R.M. Sources of particulate organic matter in surface waters of the York River, VA estuary. Organ. Geochem., v. 38, p. 365-379, 2002.

EGANHOUSE, R.P.;SHERBLOM, P.M. Anthropogenic organic contaminants in the effluent of a combined sewer overflow: impact on Boston Harbor. Mar. environ. Res., v. 51, p. $51-74,2001$.

FATTORE, E.; BENFENATI, E.; MARELLI, R.; COOLS, E. ;FANELLI, R. sterols in sediment samples from Venice Lagoon, Italy. Chemosphere,v. 33, n. 12, p. 2383-2393, 1996.

FERNANDES, M. B.; SICRE, M.-A.; CARDOSO, J. N.; MACEDO, S. J. sedimentary 4-desmethyl sterols and nalkanols in an eutrophic urban estuary, Capiberibe River, Brazil. Science total Environment, v. 231, p. 1-16, 1999.

GOÑI, M. A.; TEIXEIRA, M. J.; PERKEY, D. W. Sources and distribution of organic matter in a river-dominated estuary (Winyah Bay, SC, USA). Estuar. coast. Shelf Sci., v. 57, n.5-6, p. 1023-1048, 2003.

GRIMALT, J. O., FERNANDEZ, P., BAYONA, J.M. ALBAIGES, J. Assessment of fecal sterols and ketones as indicators of urban sewage inputs to coastal waters. Environ. Sci. Technol., v. 24, p. 357-363, 1990.

HEDGES, J. I. Global biogeochemical cycles: progress and problems. Mar. Chem.,v. 39, p.67- 93, 1992.

HOBBIE, J.E. (Ed.). Estuarine practice - a synthetic approach to research and practice. Covelo: Island Press, 2000. $245 \mathrm{p}$.

ISOBE, K. O.; TARAO, M.; CHIEM, N.H.; MIN, L.Y; TAKADA, H. Effect of environmental factors on the relationship between concentrations of coprostanol and fecal indicator bacteria in tropical (Mekong Delta) and temperate (Tokyo) freshwaters. Appl. environ. Microbiol., v. 70, n. 2, p. 814-821, 2004.

ISOBE, K. O.; TARAO, M.; ZAKARIA, M. P., CHIEM, N.; MINH, L.Y.; TAKADA, H. Quantitative application of fecal sterols using gas-chromatography - mass spectrometry to investigate fecal pollution in tropical waters: western Malaysia and Mekong Delta, Vietnam. Environ. Sci. Technol., v. 36, p. 4497-4507, 2002.

JAFFÉ, R.;GARDINALI, P. R.; CAI, Y.; SUDBURRY, A.; FERNANDEZ, A.; HAY, B.J. organic compounds and trace metals of anthropogenic origin in sediments from montego bay, jamaica: assessment of sources and distribution pathways. Environ. Pollut., v.123, n.2, p. 291-299, 2003 
JAFFÉ, R., MEAD, R., HERNANDEZ, M .E., PERALBA, M. C. ; DIGUIDA, O. A. Origin and transport of sedimentary organic matter in two subtropical estuaries: a comparative, biomarker-related study. Org. geochem v. 32, p. 507-526, 2001.

JENG, W.-L.; HAN, B.C. 1996. Coprostanol in a sediment core from the anoxic Tan-Shui estuary,Taiwan. Estuar. coast. Shelf Sci., v. 42, p. 727-735, 1996.

JENG, W.-L., WANG, J. AND HAN, B.-Coprostanol distribution in marine sediments off southwestern Taiwan. Environ. Pollut., v.94, n. 1, p. 47-52, 1996.

KNOPPERS, B., CARMOUZE, J. P.; MOREIRA-TURCQ, P. F. Nutrient dynamics, metabolism and eutrophication of lagoons along the east fluminense coast, state of Rio de Janeiro, Brazil. In: KNOPPERS, E. D.; BIDONE AND J.J. ABRÃO (Ed.). Environemtal geochemistry of coastal lagoons systems of Rio de Janeiro, Brasil. Niteroi: UFF/ Programa de Geoquímica Ambiental, 1999. p. 123-154.

LAUREILLARD, J. ;SALIOT, A. Biomarkers in organic matter produced in estuaries: a case study of the Krka estuary (Adriatic Sea) using the sterol marker series. Mar. Chem., v. 43, p: 247-261, 1993.

LEEMING, R., BALL, A., ASHBOLT, N.; NICHOLS, P.C Using faecal sterols from humans and animals to distinguish faecal pollution in receiving waters. Wat. Res., v.30, n. 12, p. 2893-2900, 1996.

LEEMING, R. ; NICHOLS, P. D. Concentrations of coprostanol that correspond to existing bacterial indicator guideline limits. Wat. Res., v. $30, \mathrm{n} .12$, p. 2997-3006, 1996.

MACKENZIE, F. T.; VER, L.M.; SABINE , C., LANE M.; LERMAN, A. C, N, P, S global biogeochemical cycles and modeling of global change. In: WOLLAST, R.; MACKENZIE, F.;. CHOU, L. (Ed.). Interactions of $\mathbf{C}$, $\mathbf{N}, \mathbf{P}$ and $\mathrm{S}$ biogeochmical cycles and global change. Berlin; Heidelberg: Springer Verlag, 1993. p 2-61, 1993. (NATO ASI Series).

MANNINO, A. ; HARVEY, H. R. Lipid composition in particulate and dissolved organic matter in the Delaware Estuary: sources and diagenetic patterns.Geochem.Cosmochim. Acta, v. 63, n. 15, p. 2219-2235, 1999.

MARTINS, C.C., FILLMANN, G. ; MONTONE, R.C. Natural and anthropogenic sterols inputs in surface sediments of Patos Lagoon, Brazil. J. Braz. Chem. Soc., v.18, n.1, p. 106-115, 2007.

McCALLEY, D.V.; COOKE, M.; NICKLESS, G. Effect of sewage treatment on faecal sterols. Wat.Res., v.15, p. 1019-1025, 1981.

MEYERS, P. A. Organic geochemical proxies of paleoceanographic, paleolimnologic, and paleoclimatic processes. Org.geochem., v. 27, n.5/6, p. 213-250, 1997.

MEYERS, P.A.; ISHIWATARI, R. The early diagenesis of organic matter in lacustrine sediments. In: ENGEL, M. H.; MACKO, S. A. (Ed.). Organic geochemistry. topics in geobiology. New York: Plenum Press, 1983. p $185-210$.

MUDGE, S. M.; LINTERN, D. Comparison of sterol biomarkers for sewage with other measures in Victoria

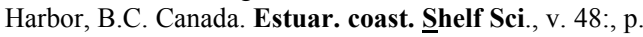
$27-38,1999$
NETTO, A. D. P.; MOREIRA, J .C.; DIAS, A. E. X. O.; ARBILLA, G.; FERREIRA, L.F.V.; OLIVEIRA, A.S. ; BAREK, J. Avaliação da contaminação humana por hidrocarbonetos policíclicos aromáticos (HPA's) e seus derivados nitrados (NHPA's): uma revisão metodológica. Química nova, v. 23, n. 6, p. 765-773, 2000

NICHOLS, P. D.; LEEMING, R.; RAYNER, M. S.; LATHAM, V.; ASHBOLT, N.; TURNER, A. Comparison of abundance of the fecal sterol coprostanol and fecal bacterial groups in inner-shelf water and sediments near Sydney, Australia. J. Chromatog., v. 643, n. 1-2, p. 189-195, 1993.

NISHIMURA , M. 5b-isomers of stanols and stanones as potential markers of sedimentary organic quality and depositional paleoenvironments. Geochim. Cosmochim. Acta, v. 46, p. 423-432, 1982.

PENG, X.; ZHANG, G.; MAI, B.; MIN, Y.; WANG, Z. Spatial and temporal trend of sewage pollution indicated by coprostanol in Maco Estuary, southern China. Mar. Pollut. Bull., v. 45, p. 295-299, 2002.

PENG, X. ; ZANG, G. ; MAI, B.; HU, J.; LI, K. ; WANG, Z. Tracing anthropogenic contamination in the pearl river estuarine and marine environment of south china sea using sterols and other organic molecular markers. Mar. Pollu. Bull., v. 50, n. 8, p. 856, 2005.

QUÉMÉNEUR, M. ;MARTY, Y. Sewage influence in a macrotidal estuary: fatty acids and sterol distributions. Estuar. coast. Shelf Sci., v. 34, p. 347-363, 1992.

QUÉMÉNEUR, M. ; MARTY, Y. Fatty acids and sterols in domestic wastewaters. Wat. Res., v. 28, n. 5, p. $1217-$ 1226, 1994.

READMAN, J.W., FILLMANN, G., TOLOSA, I., BARTOCCI, J. ; MEE, L .D. The use of steroid markers to assess sewage contamination of the black sea. Mar. Poll. Bull., v. 50, n. 3, p. 10, 2005.

REDFIELD, A. C. KETCHUM, B.H; RICHARDS, F.A. 1963. The influence of organisms on the composition of seawater. In: HILL, M. N. (Ed.) The sea. New York: John Wiley, 1963. p. 26-77, 1963.

SALIOT, A., LAUREILLARD, J., SCRIBE, P.; SICRE, M. A. Evolutionary trends in the lipid biomarker approach for investigating the biogeochemistry of organic matter in the marine environment. Mar. Chem., v. 36, p. 233248, 1991.

SALIOT, A. ; PARRISH, C. C.; SADOUNI, N.; BOULOUBASSI, I.; FILLAUX, J.; CAUWET, G. Transport and fate of danube delta terrestrial organic matter in the northwest black sea mixing zone. Mar. Chem., v, 79, p. 242-259, 2002.

SANTOS, E. S. Análise do impacto de efluentes domésticos nas enseadas de Icaraí Jurujuba esteróides como marcadores. Dissertação (Mestrado). 144 p. Universidade Federal Fluminense, Niterói/RJ. 2001.

SUN, M.-Y. ; WAKEHAM, S.G. A study of oxic/anoxic effects on degradation of sterols at the simulated sediment-water interface of coastal sediments. Org. Geochem., v. 28, n. 12, p. 773-784, 1998.

TAKADA, H., FARRINGTON, J. W., BOTNER, M. H., JOHNSON, C G.; TRIPP, B.W. Transport of sludgederived organic pollutants to deep-sea sediments at deep water dump site 106. Environ. Sci. Technol., v. 28, n. 6, p. 1062-1072, 1994 
TAKADA, H. ET AL. Anthropogenic molecular markers: tools to identify the sources and transport pathways of pollutants. In: EGANHOUSE, R. P. (Ed.). Molecular markers in environmental geochemistry. Washington: American Chemical Society, 1997. p. 178-195. (ACS Symposium Series, n. 671).

TAKADA, H.; EGANHOUSE, R.P. Molecular markers of anthropogenic waste. In: MEYERS, R. A. (Ed.) Encyclopedia of environmental analysis and remediation. New York: John Wiley, 1998. p. $2883-$ 2940 ,

TOLOSA, I.; LEBLOND, N.;COPIN-MONTÉGUT, C.; MARTY, J-C.; MORA, S. DE; PRIGUR, L. Distribution of sterols and fatty alcohols biomarkers in particulate matter from the frontal structure of the alboran sea (sw mediterranean sea). Mar. Chem., v. 82, p. $161-183,2003$

TURNER, A. AND MILLWARD, G. E. Suspended particles: their role in estuarine biogeochemical cycles. Estuar. coast. Shelf Sci., v. 55, n. 6, p. 857-883, 2002

VENKATESAN, M. I.; KAPLAN, I. R. Sedimentary coprostanol as an index of sewage addition in Santa Monica basin, southern California. Environ Sci. Technol., v. 24, p. 208-214, 1990

VER, L. M. B., MACKENZIE, F. T. ; LERMAN, A. Carbon cycle in the coastal zone: effects of global perturbations and change in the past three centuries. Chem. Geol., v. 159, p.: 283-304, 1994.

VOLKMAN, J. K. A review of sterol markers for marine and terrigenous organic matter. Org. Geochem., v. 09, n. 2, p. 83-99, 1986

VOLKMAN, J. K. ET AL. Microalgal biomarkers: a review of recent research developments. Org. Geochem., v. 29 n. 5-7, p. 1163-1179, , 1998.

VOLKMAN, J. K.; BARRET, S. M. ; BLACKBURN, S. I. Eustigmatopohyte microalgae are potential sources of $\mathrm{C}_{29}$ sterols, $\mathrm{C}_{22}-\mathrm{C}_{28}$ n-alkanols and $\mathrm{C}_{28}-\mathrm{C}_{32}$ n-alkyl diols in freshwater environments. Org. Geochem., v. 30, p. 307-318, 1999.
YUNKER, M. B.; BELICKA, L. L.; HARVEY, H. R. ; MACDONALD, R. W. Racing the inputs and fate of marine and terrigenous organic matter in arctic ocean sediments: a multivariate analysis of lipid biomarkers. Deep-Sea Research, part II: Topical Studies in Oceanography, v. 52, n. 24-26, p. 3478, 2005.

ZIMMERMAN, A.R.; CANUEL, E. A. A geochemical record of eutrophication and anoxia in Chesapeake Bay sediments: anthropogenic influence on organic matter composition. Mar. Chem., v. 69, p. 117-137, 2000.

ZIMMERMAN, A. R.; CANUEL, E. A. Sediment geochemical records of eutrophication in the mesohaline Chesapeake Bay. Limnol. Oceanogr., v. 47, n. 4, p. 1084-1093, 2002.
(Manuscript received 17 May 2007; revised 13 November 2007; accepted 29 November 2007) 